\title{
İhracat ve Itthalatın Ekonomik Büyüme Üzerindeki Etkisi: Türkiye Örneği
}

\author{
The Effects of Exports and Imports on Economic Growth: Turkey Case
}

\author{
Taha Bahadır SARAÇ
}

\begin{abstract}
ÖZET
(1989:2-2011:4) çeyrek dönemi kapsayan bu çalışmada, ihracat ve ithalatın ekonomik büyüme üzerindeki etkileri doğrusal olmayan ekonometrik yöntem ile araştırılmış ve ekonominin içerisinde bulunduğu dönemlerde daralma ve genişleme dönemlerinde ihracat ve ithalatın her iki dönemde ekonomik büyümeyi pozitif yönde etkilediği tespit edilmiştir. Bu sonuçlar ile çalışmanın kapsadığı dönem içerisinde ihracata yönelik sanayileşme stratejisinin ve içsel ekonomik büyüme teorisinin ithalat ve ekonomik büyüme ilişkisi ile ilgili görüşünün geçerli olduğu ortaya konulmuş olmaktadır.
\end{abstract}

Anahtar Kelimeler: İhracat, ithalat, ekonomik büyüme, markov rejimi, Türkiye

\section{GíRiş}

Ekonomik büyümenin kaynağı olarak dış ticaretin kapsamlı olarak klasik iktisatçılar tarafından incelendiği görülmektedir. Smith, Ricardo ve HeckscherOhlin gibi iktisatçıların ileri sürdükleri bu modellerde, dış ticaretin karşılıkı iki ülkenin dış ticaretten kazançlarını artırmalarının önemli bir aracı olduğu vurgulanmaktadır. Fakat statik bir yapıda oluşturan söz konusu bu modellerde dış ticaretin milli gelir üzerinde sadece seviye etkisi yaptığı belirtilmektedir. Diğer bir deyişle, teknolojinin ve verimliliğin sabit kabul edildiği bu modellerde dış ticaretin uzun dönem kalıcı ekonomik büyüme üzerindeki etkisine değinilmemektedir (Gross ve Helpman, 1995:1281). 1929 Dünya ekonomik krizinin ardından klasik teoriye karşıt olarak gelişen keynezyen teoride, konu gelir ve harcama ilişkisi çerçevesinde ele alınmakta ve ihracatın dış ticaret çarpanı yoluyla milli geliri artırdığı savunulmaktadır (Ispir vd., 2009:60). Solow (1956) ile başlayan ve nüfus artışı ile teknolojik değişmenin dışsal kabul edildiği neoklasik ekonomik büyüme modellerinde ise politika uygulamaları ile ekonomik büyüme arasında bir ilişki kurulmamaktadır. Dolayısıyla da bu modellerde dış ticaret politikalarıyla uzun dönem ekonomik büyüme oranı üzerinde bir etki oluşturulamayacağı kabul edilmektedir

\begin{abstract}
In this study, we aim to investigate the effects of exports and imports on economic growth during the quarter period of (1989:2-2011:4) by using nonlinear econometric technique. We have found that exports and imports effect economic growth positively during the contraction and expansion periods of economy. With the helps of this study, it is proved that in Turkish economy within the study period, export-oriented industrialization strategy and endogenous economic growth theory's views on the relationship between imports and economic growth is valid.
\end{abstract}

Keywords: Export, import, economic growth, markov regime, Turkey

(Shaw, 1992:611; Utkulu ve Özdemir, 2004: 245,246). Buna karşılık, Romer (1986)'daki çalışmasıyla ortaya çıkan içsel ekonomik büyüme modellerinde, teknolojik gelişmenin iktisadi sistem içerisinde oluştuğu ve iktisadi kararlardan etkilendiği ifade edilmektedir. Buna göre bu modellerde, hükümetlerin, özellikle beşeri sermaye ve araştırma-geliştirme çalışmalarına yönelik destekleyici nitelikteki kararları ile uzun dönem ekonomik büyüme oranına katkıda bulunabileceklerine değinilmektedir (Çiftçi ve Aykaç, 2011:162,163). Böylelikle de, hükümetler dış ticareti teşvik ederek teknoloji transfer edebilmekte ve uzun dönem ekonomik büyümelerini olumlu yönde etkileyebilmektedirler (Gross ve Helpmann, 1994). Teorik yaklaşımların politika uzantıları incelendiğinde ise, tarihsel açıdan yeni sanayileşmeye başlayan ülkelerde kalkınma çabalarına ithal ikameci sanayileşme stratejisi ile başlanıldığı fakat daha sonra söz konusu bu ülkelerin ileriki dönemlerde ihracata yönelik sanayileşme stratejisini benimsedikleri ileri sürülmektedir (Seyidoğlu, 2007:514). Bu durumun oluşmasında ise, özellikle 1950 'lerde ithal ikameci sanayileşme stratejisini uygulayan ülkelerde iç pazarın dar olması nedeniyle üretim artışı ile ortaya çıkan satış sorununun etkin ölçekte sanayilerin kurulmasını olumsuz etkilemesi ile yüksek tarifeler ve miktar kısıtlamaları 
ile uzun süre korunan ithal ikamesi sanayi dallarının yabancı rekabetten uzaklaşmasının etkili olduğu iddia edilmektedir (Karluk, 2009:398). 1980'li yıllarda gelişen ihracata yönelik sanayileşme stratejisinde ise, sanayileşme ve ekonomik büyüme için gerekli motivasyonu iç talepten çok dış talep oluşturmaktadır (Kazgan, 1998:618). Bu anlamda, temelde dış ticaret ile ekonomik büyüme arasındaki ilişkiye dayandırılan ihracata yönelik sanayileşme stratejisi kapsamında özellikle mamul mal ihracatının özendirilmesi ve bunun ekonomik büyüme üzerindeki olumlu etkileri ortaya çıkartılmaya çalışılmaktadır. Söz konusu bu etkiler ise; kaynakların karşılaştırmalı üstünlüklerin olduğu alanlara kayması emek faktörünün bol olduğu ülkelerde istihdamın artması, dış ticaret rejiminin serbestleşmesi sonucunda kapasite kullanımının artması, ölçek genişlemesi ve ölçek ekonomilerinden yararlanılması, ihracatın teşvik edilerek firmaların dış rekabete açılmalarının sağlanması ve rekabetin etkisiyle verimlilik artışlarının ve yeni teknolojilerin kullanımının gerçekleşmesi şeklinde sıralanmaktadır (Akt: Egeli, 2001:154). Bu noktada, Türkiye ekonomisi incelendiğinde, 1980'e kadar ki dönemin genelinde ithal ikameci sanayileşme stratejisinin, bu tarihten sonra ise ihracata yönelik sanayileşme stratejisinin benimsendiği görülmektedir. 1980 sonrası izlenen ihracat yönelik sanayileşme stratejisi kapsamında, 1980'de 11.9 olan toplam ihracat ve ithalatın GSYiH (Gayrisafi Yurt Içi Hasıla)'ya oranının, 2011'de 56.5'e yükseldiği tespit edilmektedir'. Dışa açıklık oranı şeklinde ifade edilen bu değerdeki artışın ekonomik büyüme üzerindeki etkisi, dış ticaretin bileşimini oluşturan ihracat veya ithalat kanalıyla gerçekleşmektedir. Buna göre, milli gelir hesaplamalarında ihracat, GSYiH'ya pozitif bir katkı sağlayıp ekonomik büyüme oranının yükselmesine katkıda bulunabileceği gibi ithalat da GSYiH üzerinde negatif bir etkide bulunabilmektedir. Bununla birlikte, ara malı ve teknoloji ithalatı ise ekonomik verimliliğin artmasını sağlayarak ihracat ve GSYiH üzerinde pozitif bir etki meydana getirebilmektedir (Güngör ve Kurt, 2007:197,198). Bu bağlamda, hazırlanan bu çalışmada ihracat ve ithalatın ekonomik büyüme üzerindeki etkilerinin ortaya konulması amaçlanmaktadır. Konu ile ilgili geniş bir literatürün oluştuğu gözönüne alındığında diğer bir çok çalışmadan farklı olarak, ekonominin büyümenin daraldığı ve genişlediği dönemlerde ihracat ve ithalatın ekonomik büyüme üzerindeki etkilerinin belirlenmesi, bu çalışmanın temel motivasyonunu oluşturmaktadır. Bu amaç doğrultusunda dört bölüm şeklinde hazırlanan çalışmanın ikinci bölümünde konu ile ilgili literatür incelenmiş, üçüncü bölümde ise çalışmada benimsenen model hakkında bilgi verilmiştir. Ekonometrik yöntem ve uygulama sonuçlarının yer aldığı dördüncü bölümünün ardından sonuç bölümü ile de çalışma tamamlanmıştır.

\section{LITERATÜR ÖZETI}

İhracatın ve ithalatın ekonomik büyüme üzerindeki etkilerini konu alan geniş bir literatürün oluştuğu görülmektedir. Bu çalışmalardan örneğin; Kravis (1970), Michaely (1977), Bhagwati (1978), Balassa (1978, 1985), Tyler (1981), Kavoussi (1984), Ram (1985), Jung ve Marshall (1985), Gonclaves ve Richtering (1986), Ram (1987), Heitger (1987), Fosu (1990), Lussier (1993), Bahmani-Oskooee vd. (1993), Dutt ve Ghosh (1996), Xu (1996), Islam (1998), Hatemi ve Irandoust (2000), Tsen (2002), Awokuse (2002), Hatemi (2002), Mah (2005), Konya (2006), Siliverstovs ve Herzer (2006), Bahmani-Oskooee vd. (2007), Parida ve Sahoo (2007), Galimberi (2009), Tang ve Lai (2011) ihracatın ekonomik büyümeyi olumlu yönde etkilediği sonucuna ulaşırken; Esfahani (1991), Lee (1995), Zhang ve Zou (1995), Mody ve Yılmaz (2002), Chuang (2002), Li ve vd. (2003), Alam (2003), Pawlos (2004) ise ithalatın ekonomik büyümeyi olumlu yönde etkilediği sonucuna ulaştıkları tespit edilmektedir (Shirazi ve Manap, 2004: 563-567; Medina-Smith, 2001: 6-9; Gerni vd., 2008: 8; Çetintaş ve Barışık, 2009: 638-640; Safdari vd., 2011: 40-41). Konu ile ilgili olarak Türkiye ekononomisi üzerine gerçekleştirilen çalışmalar ise Tablo 1'de şu şekilde özetlenmiştir.

\section{MODEL}

Bu çalışmada, Ram (1985)'ın geliştirdiği model benimsenmiştir. Modelin oluşturulması için öncelikle (1) no'lu denklemde belirtilen toplam üretim fonksiyonu oluşturulmuştur.

$$
Y=f(L, K, X)
$$

(1) no'lu denklemde $Y$ toplam reel üretimi, L emek girdisini, $\mathrm{K}$ sermaye girdisini ve $\mathrm{X}$ ise ihracatı göstermektedir. (1) no'lu denklemin toplam türevi alındığında (2) no'lu denkleme ulaşılmaktadır.

$$
d Y=\frac{\partial Y}{\partial L} \cdot d L+\frac{\partial Y}{\partial K} \cdot d K+\frac{\partial Y}{\partial X} \cdot d X
$$

(2) no'lu denklem $Y^{\prime}$ ye bölündüğünde ise (3) no'lu denklem elde edilmektedir.

$$
\frac{d Y}{Y}=\frac{\partial Y / Y}{\partial L / L} \cdot \frac{d L}{L}+\frac{\partial Y / Y}{\partial K / K} \cdot \frac{d K}{K}+\frac{\partial Y / Y}{\partial X / X} \cdot \frac{d X}{X}
$$

(3) no'lu denkleme sabit terimin de ( $\left.\beta_{0}\right)$ ilave edilmesiyle (4) no'lu denklem oluşturulmaktadır. 
Tablo 1: Çalıșmanın Konusu ile Illgili Türkiye Üzerine Yapılan Çalıșmaların Özeti

\begin{tabular}{|c|c|c|c|}
\hline Yazar (lar) & Dönem & Yöntem & Sonuç \\
\hline $\begin{array}{l}\text { Yiğidim vd. } \\
\text { (1997) }\end{array}$ & 1980:1-1996:4 & $\begin{array}{l}\text { Granger Nedensellik } \\
\text { Testi }\end{array}$ & $\begin{array}{l}\text { İthalattan ekonomik büyümeye doğru bir nedensellik ilişkisi } \\
\text { olduğunu tespit etmişlerdir. }\end{array}$ \\
\hline $\begin{array}{c}\text { Özmen } v d \text {. } \\
\text { (1998) }\end{array}$ & 1970-1995 & Eşbütünleşme Testi & $\begin{array}{l}\text { Ihracata yönelik sanayileşme hipotezinin geçerli olmadığını } \\
\text { belirlemişlerdir. }\end{array}$ \\
\hline $\begin{array}{c}\text { Özmen } v d . \\
\text { (1999) }\end{array}$ & 1987:1-1997:6 & $\begin{array}{l}\text { Granger Nedensellik } \\
\text { Testi }\end{array}$ & $\begin{array}{l}\text { İhracattan ekonomik büyümeye doğru tek yönlü bir nedensellik } \\
\text { ilişkisi tespit etmişlerdir. }\end{array}$ \\
\hline $\begin{array}{l}\text { Tuncer } \\
(2002)\end{array}$ & $\begin{array}{l}\text { 1980:01- } \\
\text { 2000:04 }\end{array}$ & $\begin{array}{l}\text { Toda-Yamamoto } \\
\text { Nedensellik Testi }\end{array}$ & $\begin{array}{l}\text { İhracattan GSYiH'ya doğru tek yönlü bir nedensellik ilişkisi } \\
\text { olmadığı, GSYiH'dan ihracata tek yönlü bir nedensellik ilişkisi } \\
\text { olduğu ve ithalat ile GSYiH arasında karşılıklı bir nedensellik ilişkisi } \\
\text { olduğunu belirlemiştir. }\end{array}$ \\
\hline $\begin{array}{l}\text { Şimşek } \\
(2003)\end{array}$ & 1960-2002 & $\begin{array}{l}\text { Eşbütünleşme ve } \\
\text { Granger Nedensellik } \\
\text { Testleri }\end{array}$ & $\begin{array}{l}\text { Ekonomik büyümeden ihracata doğru tek yönlü bir nedensellik } \\
\text { ilişkisi olduğunu tespit etmiştir. }\end{array}$ \\
\hline $\begin{array}{l}\text { Ay vd. } \\
(2004)\end{array}$ & $1980-2003$ & $\begin{array}{c}\text { Granger Nedensellik } \\
\text { Testi } \\
\end{array}$ & $\begin{array}{l}\text { İhracat ile ekonomik büyüme arasında karşııklı bir nedensellik } \\
\text { ilişkisi olduğu sonucuna ulaşmışlardır. }\end{array}$ \\
\hline $\begin{array}{l}\text { Nişancı } \\
(2005)\end{array}$ & $1962-2003$ & $\begin{array}{l}\text { Eşbütünleşme, Hata } \\
\text { Düzeltme ve Granger } \\
\text { Nedensellik Testleri }\end{array}$ & $\begin{array}{l}\text { İhracattan ekonomik büyümeye doğru güçlü bir nedensellik ilişkisi } \\
\text { olduğunu tespit etmiştir. }\end{array}$ \\
\hline $\begin{array}{l}\text { Demirhan } \\
\text { (2005) }\end{array}$ & 1990:1-2004:1 & $\begin{array}{l}\text { Eşbütünleşme, Hata } \\
\text { Düzeltme ve Granger } \\
\text { Nedensellik Testleri }\end{array}$ & $\begin{array}{l}\text { Ihracattan ekonomik büyümeye doğru bir nedensellik ilişkisi } \\
\text { olduğunu ve uzun dönemde ihracatın ekonomik büyümeyi } \\
\text { artırdığını belirlemiştir. }\end{array}$ \\
\hline $\begin{array}{c}\text { Erdoğan } \\
(2006)\end{array}$ & 1923-2004 & $\begin{array}{l}\text { Eşbütünleşme ve } \\
\text { Granger Nedensellik } \\
\text { Testleri }\end{array}$ & $\begin{array}{l}\text { Ihracat ile ekonomik büyüme arasında eşbütünleşme ilişkisi } \\
\text { olduğunu ve aralarında iki yönlü nedensellik olduğu sonucuna } \\
\text { ulaşmıştır. }\end{array}$ \\
\hline $\begin{array}{l}\text { Özer vd. } \\
(2006)\end{array}$ & 1987:1-2006:2 & VAR Analizi & $\begin{array}{l}\text { Ihracattan ve ithalattan ekonomik büyümeye doğru tek yönlü bir } \\
\text { nedensellik ilişkisi olduğunu tespit etmişlerdir. }\end{array}$ \\
\hline $\begin{array}{c}\text { Kösekahyaoğlu } \\
v d .(2006)\end{array}$ & $1980-2005$ & $\begin{array}{l}\text { Granger Nedensellik } \\
\text { Testi }\end{array}$ & $\begin{array}{l}\begin{array}{l}\text { Ihracattan ithalata doğru güçlü bir nedensellik ilişki } \\
\text { belirlemişlerdir. }\end{array} \\
\end{array}$ \\
\hline $\begin{array}{l}\text { Yapraklı } \\
(2007)\end{array}$ & 1970-2005 & $\begin{array}{l}\text { Granger Nedensellik } \\
\text { Testi }\end{array}$ & $\begin{array}{l}\text { Ihracata yönelik sanayileşme stratejisinin geçerli olduğunu } \\
\text { belirlemiştir. }\end{array}$ \\
\hline $\begin{array}{c}\text { Taban } v d \text {. } \\
(2008)\end{array}$ & 1980:1-2007:2 & $\begin{array}{l}\text { Eşbütünleşme ve Hata } \\
\text { Düzeltme Testleri }\end{array}$ & $\begin{array}{l}\text { Kısa ve uzun dönemde ihracattan ekonomik büyümeye doğru tek } \\
\text { yönlü bir nedensellik ilişkisi olduğu sonucuna ulaşmışlardır. }\end{array}$ \\
\hline $\begin{array}{l}\text { Gerni } v d \text {. } \\
\text { (2008) }\end{array}$ & 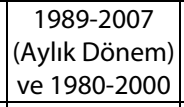 & $\begin{array}{l}\text { Regresyon ve Granger } \\
\text { Nedensellik Testleri }\end{array}$ & $\begin{array}{l}\text { İhracatın ekonomik büyüme üzerindeki etkisinin ithalat aracılığıyla } \\
\text { ortaya çıktığını tespit etmişlerdir. }\end{array}$ \\
\hline $\begin{array}{l}\text { Uğur } \\
(2008)\end{array}$ & 1994:1-2005:4 & VAR Analizi & $\begin{array}{l}\text { Ara malı ve yatıım malı ithalatı ile GSYiH arasında karşııklı bir } \\
\text { nedensellik ilişki belirlemiştir. }\end{array}$ \\
\hline $\begin{array}{l}\text { Aktaş } \\
(2009)\end{array}$ & $\begin{array}{l}\text { 1996:01- } \\
\text { 2006:06 }\end{array}$ & $\begin{array}{l}\text { Eşbütünleşme ve Hata } \\
\text { Düzeltme Testleri }\end{array}$ & $\begin{array}{l}\text { İthalat, ihracat ve ekonomik büyüme arasında eşbütünleşme ilişkisi } \\
\text { olduğu, kısa dönemde ithalat, ihracat ve ekonomik büyüme } \\
\text { arasında iki yönlü nedensellik ilişkisi olduğu ve uzun dönemde ise } \\
\text { ihracattan ithalata, ithalattan ihracata, ekonomik büyümeden } \\
\text { ihracata ve ekonomik büyümeden ithalata doğru tek yönlü bir } \\
\text { nedensellik ilişkisi olduğunu tespit etmiştir. }\end{array}$ \\
\hline $\begin{array}{l}\text { Bilgin } v d \text {. } \\
\quad(2009)\end{array}$ & $\begin{array}{l}1987: 1- \\
2007: 12\end{array}$ & $\begin{array}{l}\text { Hata Düzeltme Modeli } \\
\text { ve Toda-Yamamoto } \\
\text { Nedensellik Testi }\end{array}$ & $\begin{array}{l}\text { İhracattan sanayi üretim endeksine tek yönlü bir nedensellik ilişkisi } \\
\text { olduğu sonucuna ulaşmışlardır. }\end{array}$ \\
\hline $\begin{array}{l}\text { İspir vd. } \\
\text { (2009) }\end{array}$ & 1989:1-2007:4 & Markov Rejim Modeli & $\begin{array}{l}\text { Daralma döneminden genişleme dönemine geçerken ihracatın } \\
\text { etkili olduğu, ekonomi genişleme döneminde iken bu sürecin } \\
\text { sürdürülmesinde ihracat ve ithalatın birlikte katkı sağladıklarını } \\
\text { fakat bu katkının azaldığını tespit etmişlerdir. }\end{array}$ \\
\hline $\begin{array}{l}\text { Soyyiğit vd. } \\
\text { (2010) }\end{array}$ & 1990-2008 & $\begin{array}{l}\text { Toda-Yamamoto } \\
\text { Nedensellik Testi }\end{array}$ & $\begin{array}{l}\text { İmalat sanayi ihracatının ve GSYiH'nın ara ve yatırım malı ithalatına } \\
\text { bağımlı olduğunu tespit etmişlerdir. }\end{array}$ \\
\hline $\begin{array}{l}\text { Şimşek vd. } \\
\text { (2010) }\end{array}$ & $1960-2004$ & $\begin{array}{l}\text { Sınır Testi ve Hata } \\
\text { Düzeltme Modeli }\end{array}$ & $\begin{array}{l}\text { Uzun dönemde ihracattan ekonomik büyümeye tek yönlü } \\
\text { nedensellik ilişkisi olduğunu ortaya koymuşlardır. }\end{array}$ \\
\hline $\begin{array}{l}\text { Kotil vd. } \\
(2010)\end{array}$ & 1989:1-2007:3 & $\begin{array}{l}\text { Granger Nedensellik } \\
\text { Testi }\end{array}$ & $\begin{array}{l}\text { İhracattan ekonomik büyümeye doğru tek yönlü bir nedensellik } \\
\text { ilişkisi tespit etmişlerdir. }\end{array}$ \\
\hline $\begin{array}{l}\text { Temiz vd. } \\
\text { (2010) }\end{array}$ & 1950-2009 & $\begin{array}{l}\text { Eşbütünleşme, Hata } \\
\text { Düzeltme ve Granger } \\
\text { Nedensellik Testleri }\end{array}$ & $\begin{array}{l}\text { Ekonomik büyümeden ihracata yönelik tek yönlü bir nedensellik } \\
\text { ilişkisi olduğunu belirlemişlerdir. }\end{array}$ \\
\hline $\begin{array}{l}\text { Takım } \\
(2010)\end{array}$ & $1975-2008$ & $\begin{array}{l}\text { Granger Nedensellik } \\
\text { Testi }\end{array}$ & $\begin{array}{l}\text { İhracat artışlarının ekonomik büyümedeki artışı desteklemediği } \\
\text { sonucuna ulaşmıştır. }\end{array}$ \\
\hline
\end{tabular}




$$
\dot{Y}_{t}=\beta_{0}+\beta_{1} \dot{L}_{t}+\beta_{2} \dot{K}_{t}+\beta_{3} \dot{X}_{t}
$$

(4) no'lu denklemde $\dot{Y}_{t}$ ekonomik büyüme oranını, $\dot{L}_{t}$ istihdam hacmi büyüme oranını, $\dot{K}_{t}$ sermaye stoku büyüme oranını, $\dot{X}_{t}$ ihracat hacmi büyüme oranını, $\beta_{1}, \beta_{2}$ ve $\beta_{3}$ sırasıyla istihdam, sermaye stoku ve ihracatın ekonomi büyümeyi ne ölçüde etkilediğini gösteren katsayıları ifade etmektedir. (4) no'lu denklemde sermaye stoku verisinin çoğu ülke için tespit edilememesi nedeniyle (3) no'lu denklemde $d K$ yerine $I$ (yatııı harcamaları) değişkeninin kullanılması tercih edilmektedir. Buna göre, (4) no'lu denklem (5) no'lu denkleme dönüşmektedir.

$$
\dot{Y}_{t}=\beta_{0}+\beta_{1} \dot{L}_{t}+\beta_{2} \frac{I_{t}}{Y}+\beta_{3} \dot{X}_{t}
$$

Ayrıca, çalışmada ithalatın değişkenin ekonomik büyüme üzerindeki etkisi de araştırılmak istenildiği için (4) modelde $\dot{X}_{t}$ ihracat hacmi büyüme oranını değişkeni yerine $\dot{M}_{t}$ ithalat hacmi büyüme oranı dahil edilerek (6) no'lu modelin oluşturulması da uygun görülmüştür (Ram, 1985: 417, 424).

$$
\dot{Y}_{t}=\beta_{0}+\beta_{1} \dot{L}_{t}+\beta_{2} \frac{I_{t}}{Y}+\beta_{3} \dot{M}_{t}
$$

\section{EKONOMETRIK YÖNTEM VE UYGULAMA SONUÇLARI}

\subsection{Ekonometrik Yöntem}

Markov süreci, olasılıkların bir önceki olasılıklarla açıklandığı stokastik bir süreç olarak tanımlanmaktadır. Buna göre, $t-1$ ve $t$ dönemlerindeki rejimler arasındaki ilişkiler açıklayan markov değişim modeli (7) no'lu denklem ile ifade edilmektedir.

$$
P\left\{s_{t}=j \mid s_{t-1}=i\right\}=P\left\{s_{t}=j \mid s_{t-1}=i, s_{t-2}=k, \ldots\right\}=p_{i j}
$$

(7) no'lu denklemde, rejim $i^{\prime}$ den rejim $j^{\prime}$ ye geçiş olasılığını göstermektedir. Dolayısıyla ekonomide iki rejim olduğu kabul edildiğinde ve bu rejimler $s_{t}=0$ (düşük ekonomik büyüme) ve $s_{t}=1$ (yüksek ekonomik büyüme) olarak oluşturulduğunda iki rejimli bir yapıdan diğer rejime geçiş (8), (9), (10) ve (11) no'lu denklemler ile belirtilmektedir.

$$
\begin{aligned}
& \operatorname{Pr}\left[s_{t}=1 \mid s_{t-1}=1\right]=p_{11}=p \\
& \operatorname{Pr}\left[s_{t}=0 \mid s_{t-1}=1\right]=p_{10}=1-p \\
& \operatorname{Pr}\left[s_{t}=0 \mid s_{t-1}=0\right]=p_{00}=q \\
& \operatorname{Pr}\left[s_{t}=1 \mid s_{t-1}=0\right]=p_{01}=1-q
\end{aligned}
$$

Geçiş olasılıkları matris formunda (12) no'lu denkleme dönüşmektedir.

$$
P=\left[\begin{array}{cc}
q & 1-q \\
1-p & p
\end{array}\right]
$$

(12) no'lu denklemdeki matris iki rejimli geçiş olasılıkları matrisi olarak tanımlanmakla birlikte matrisde yer alan geçiş olasıklarının sabit olduğu kabul edilmektedir. Bununla beraber rejim değişkeni $S_{t}$ 'nin doğrudan gözlenemediği sadece $y_{t}$ olarak gösterilen ekonomik ve finansal değişken veya değişkenlerin gözlenebildiği, $y_{t}$ serisinin özelliklerinin de gözlenemeyen ama içinde bulunduğu rejim değişkenine bağı olduğu ve gözlenemeyen bir $y_{t}$ serisinin herhangi bir istatistiksel özelliğinin rejim ile birlikte değiştiği kabul edilmekte ve (13), (14) no'lu denklemler ile gösterilmektedir.

$$
\begin{aligned}
& E\left[y_{t} \mid s_{t}=0\right]=\mu_{0} \\
& E\left[y_{t} \mid s_{t}=0\right]=\mu_{1}
\end{aligned}
$$

Örneğin, ekonomik büyüme oranı $y_{t}$ ve $s_{t}=0$ daralma ve $s_{t}=1$ genişleme rejimi olarak ifade edildiğinde $\mu_{0}$ (daralma dönemindeki ortalama) ve $\mu_{1}$ (genişleme dönemindeki ortalama) arasında $\mu_{1}>\mu_{0}$ şeklinde (15) no'lu denklem ile belirtilen bir ilişki ortaya çıkmaktadır.

$$
\mu\left(s_{t}\right)= \begin{cases}s_{t}=1 & \text { ise } \mu_{1}>0 \\ s_{t}=0 & \text { ise } \mu_{0}<0\end{cases}
$$

Daha genel olarak 'nin bir otoregresif süreç özelliğine sahip ve $\delta_{s t}$ 'nin sabit terimi, $\varepsilon_{t}{ }^{\prime}$ 'nin hata terimini, $\phi_{1} . . \phi_{p}$ 'lerin değişken katsayılarını gösterdiği durumda, söz konusu süreç $A R(p)$ şeklinde ifade edilirse (16) no'lu denkleme ulaşılmaktadır.

$$
y_{t}=\delta_{s t}+\phi_{1} y_{t-1}+\ldots+\phi_{p} y_{t-p}+\varepsilon_{t}, \quad \varepsilon_{t} \sim N\left(0, \sigma^{2}\right)
$$

(16) no'lu denkleme $x_{t}$ bağımsız değişkeninin dahil edilmesiyle sabit terimin $v$, değişken parametrelerinin sırasıyla $\alpha_{j}$ ve $\beta_{i}$ olarak tanımlandığı (17) no'lu denklem ile belirtilen $\operatorname{MSIA}(M)-A R X(p)$ şeklinde isimlendirilen model elde edilmektedir. Bu modelde, MS (Markov Switching-Markov Değişimi), $M$ (Rejim Sayısını), $p$ (Gecikme Uzunluğunu), I (sabit terimi), $A$ (otoregresif sürecin parametrelerini) ve $X$ (bağımsız değişken parametrelerini) göstermektedir.

$$
y_{t}=v\left(s_{t}\right)+\sum_{i=1}^{p} \alpha_{j}\left(s_{t}\right) y_{t-i}+\sum_{j=0}^{n} \beta_{i}\left(s_{t}\right) X_{t-j}+\varepsilon_{t}
$$

Buna göre, (17) no'lu denklem tahmin edilirken öncelikle $Y_{t}$ 'nin gözlemleri $s_{t}=1$ ile $s_{t}=0$ 'ya denk gelen gözlemler olarak ayrıştııılmaktadır. Daha sonra sırasıyla ilk grupta ve ikinci grupta yer alan gözlemler kullanılarak en küçük kareler yöntemi ile (17) no'lu denkleme ait parametreler tahmin edilmektedir. Bu tahmin işleminin ardından (18) ve (19) no'lu denklemler ile belirtilen rejim olasılıkları hesaplanmaktadir. 


$$
\begin{gathered}
\hat{p}=\frac{\#\left(s_{t-1}=1, s_{t}=1\right)}{\#\left(s_{t-1}=1\right)} \\
\hat{q}=\frac{\#\left(s_{t-1}=0, s_{t}=0\right)}{\#\left(s_{t-1}=0\right)}
\end{gathered}
$$

(18) ve (19) no'lu denklemlerde yer alan \# (.) , örneklemde parantez içindeki olayın kaç defa tekrarlandığını ifade etmektedir. Burada hesaplanan olasıklar koşullu olasıkların tahminleri olmakla birlikte parametre tahminleri EM (Expectation MaximizationMaksimum Beklenti) algoritması ile aşağıdaki aşamalar ile gerçekleştirilmektedir.

1) Öncelikle $Y_{t}$ gözlemleri $t=1, \ldots, T$ olmak üzere iki rejime ayrıştırılmaktadır.

2) Bu şekilde ayrıştırılmış gözlemlerden yardımıyla beraber (17) no'lu denklemde yer alan parametreler tahmin edilmektedir.

3) $\operatorname{Pr}\left[s_{t}=1 \mid Y_{T}\right]$ şeklinde gösterilen olasılıkları hesaplamak amacıyla ikinci aşamada yer alan parametrelerin tahminleri kullanılmaktadır.
4) Bu aşamada ise yer alan düzgünleştirilmiş olasılıklar yardımıyla gözlemler iki rejime tekrar konulmaktadır. Dolayısıyla düzgünleştirilmiş rejim olasılıkları ile ağırlıklandırılmış gözlemler ile (17) no'lu modele ait parametreler, $p$ ve $q$ tekrar tahmin edilmektedir.

5) Parametre tahminlerinin süreç tekrarlandığında etkin bir şekilde değişmediği belirleninceye kadar üçüncü ve dördüncü aşamadaki işlemlerin gerçekleştirilmesine devam edilmektedir (Bildirici ve Bozoklu, 2007:3-5, Koç, 2008: 74-76, Krolzig, 1998 ve Clements vd., 2004).

\subsection{Uygulama Sonuçları}

\subsubsection{Veri Seti ve Değişkenler}

Çalışmada 1989:2-2011:4 dönemine ait çeyrek dönem veriler kullanılmıştır. İlgili verilerin oluşturulmasında TÜik (Türkiye İstatistik Kurumu) ve TCMB (Türkiye Cumhuriyet Merkez Bankası) EVDS (Elektronik Veri Dağıtım Sistemi) veri tabanlarından yararlanılmıştır.

\begin{tabular}{|c|c|}
\hline Değişkenler & Tanımlamaları \\
\hline$(\dot{Y})$ & : $\quad$ Reel ekonomik büyüme oranı \\
\hline$(\dot{L})$ & : İstihdam hacmi büyüme oranı \\
\hline$(I / Y)$ & : $\quad$ Toplam yatıım harcamalarının GSYiH içerisindeki oranı \\
\hline$(\dot{X})$ & : Reel ihracat hacmi büyüme oranı \\
\hline$(\dot{M})$ & : $\quad$ Reel ithalat hacmi büyüme oranı \\
\hline \multicolumn{2}{|c|}{$\begin{array}{l}\text { (Not: 1.Büyüme oranlarının hesaplanmasında ilgili değişkenlerin doğal } \\
\text { logaritmalarıalındıktan sonra birinci farkları alınmıştır. 2.İstihdam hacmi büyüme } \\
\text { oranı dışındaki diğer değişkenler deflatör baz yılı } 1998 \text { kabul edilerek } \\
\text { hesaplanmıştır. 3.İstihdam hacmi ise işgücü içerisinde yer alan çalışan sayıları } \\
\text { kullanılarak hesaplanmıştır. 4. 1989-2000 döneminde ait istihdam verileri altı aylık } \\
\text { dönemler halinde hesaplandığından kubik spline yöntemi kullanılarak ilgi veriler } \\
\text { çeyrek verilere dönüştürülmüştür. Bknz. Barışık vd., 2010: 94.) }\end{array}$} \\
\hline
\end{tabular}

Tablo 2: Değişkenler ve Tanımlamaları

\subsubsection{Ekonometrik Analiz Sonuçları}

\subsubsection{Birim Kök Test Sonuçları}

$\operatorname{MSIA}(M)-A R X(p)$ uygulamasında yer alan serilerin durağan olmaları gerekmektedir. Bu nedenle çalışmada kullanılan serilerin durağan olup olmadıkları serilerdeki kırılmaları dikkate alan ve bu yönüyle söz konusu kırılmaları dikkate almayan geleneksel birim kök testleri yerine tercih edilen Lee-Strazicich birim kök testiyle incelenmiş ve test sonuçları Tablo 3' te gösterilmiştir.
Tablo 3'deki sonuçlara göre serisinin birinci fark değerinde, diğer serilerin ise seviye değerlerinde durağan oldukları tespit edilmiştir.

\subsubsection{2. $M S I A(M)-A R X(p)$ Analizi Sonuçları}

$\operatorname{MSIA}(M)-A R X(p)$ analizi gerçekleştirilmeden önce ihracat ve ithalat değişkenin yer aldığı modeller için uygun gecikme uzunluğu Tablo 4'de de görüleceği üzere Schwarz Bilgi Kriterlerine göre 1 (bir) olarak belirlenmiştir. 1 (bir) gecikme ile gerçekleştirilen modellerin tahmin sonuçları ise Tablo 5'de sunulmuştur. 
Tablo 3: Lee-Strazicich Birim Kök Test Sonuçları

\begin{tabular}{|c|c|c|c|}
\hline \multirow{2}{*}{ Seriler } & \multirow{2}{*}{ (t-istatistik) Değerleri } & \multicolumn{2}{|c|}{ Kırılma Tarihleri } \\
\cline { 3 - 4 }$(\dot{Y})$ & $-9.11(0)$ & $1993: 2$ & $1999: 1$ \\
\hline$(\dot{L})$ & $-10.59(4)$ & $1999: 4$ & $2005: 1$ \\
\hline$(I / Y)$ & $-5.18(8)$ & $2000: 3$ & $2006: 1$ \\
\hline$(\dot{X})$ & $-10.99(0)^{*}$ & $2000: 4$ & $2001: 3$ \\
\hline$(\dot{M})$ & $-6.53(7)$ & $1997: 2$ & $2003: 3$ \\
\hline
\end{tabular}

(Note: 1.Parantez içerisindeki değerler uygun gecikme uzunluklarını ifade etmektedir. Belirtilen gecikme uzunluklarında hata terimleri arasında ilişki olmadığı belirlenmiştir. 2.Farklı kırılma yılları dönemleri için yüzde 10 önem düzeyindeki kritik değerler -5.27, 5.32, -5.33 şeklinde tespit edilmiştir. Bknz. Lee ve Strazicich, 2003:1084. Ayrıca kırılma yıllarının nasıl belirlendiği konusunda bknz. Lee ve Strazicich, 2003. 3.(*) ilgili değişkenin birinci farkı alındıktan sonra elde edilen sonuçları ifade etmektedir.)

Tablo 4: Gecikme Uzunluklarının Belirlenmesi

\begin{tabular}{|c|c|c|c|}
\hline \multicolumn{2}{|c|}{$\begin{array}{c}\text { Ihracat Değişkeninin Yer Aldığı } \\
\text { Model İçin Uygun Gecikme } \\
\text { Uzunluğunun Belirlenmesi }\end{array}$} & $\begin{array}{c}\text { İthalat Değişkeninin Yer Aldığı } \\
\text { Model Iç̧in Uygun Gecikme } \\
\text { Uzunluğunun Belirlenmesi }\end{array}$ \\
\hline $\begin{array}{c}\text { Gecikme } \\
\text { Uzunlukları }\end{array}$ & $\begin{array}{c}\text { Schwarz Bilgi } \\
\text { Kriteri İstatistik } \\
\text { Değeri }\end{array}$ & $\begin{array}{c}\text { Gecikme } \\
\text { Uzunlukları }\end{array}$ & $\begin{array}{c}\text { Schwarz Bilgi } \\
\text { Kriteri İstatistik } \\
\text { Değeri }\end{array}$ \\
\hline 1 & -4.2721 & 1 & -4.6201 \\
\hline 2 & -4.0349 & 2 & -4.3566 \\
\hline 3 & -3.7989 & 3 & -4.1819 \\
\hline
\end{tabular}

Tablo 5'deki doğrusallık testi sonuçlarından da görüleceği üzere ihracat veya ithalatın yer aldığı modellerde doğrusal olmayan bir ilişki belirlenmiştir. Buna göre, elde sonuçlar yorumlandığında, ekonominin daralma döneminde ihracat değişkeninin bir dönem gecikmeli değerinde meydana gelen bir birimlik değişme ekonomik büyümede 0.6604 birim değişmeye, genişleme döneminde ihracat değişkeninin cari dönem değerinde meydana gelen bir birimlik değişme ekonomik büyümede 0.2639 birim değişmeye ve ihracat değişkeninin bir dönem gecikmeli değerinde meydana gelen bir birimlik değişme ekonomik büyüme üzerinde 0.0769 birim değişmeye neden olurken; daralma döneminde ithalat değişkeninin cari dönem değerinde meydana gelen bir birimlik değişme ekonomik büyüme üzerinde 0.2921 birim değişmeye ve ithalat değişkeninin bir dönem gecikmeli dönem değerinde meydana gelen bir birimlik bir değişme ekonomik büyümede 0.1421 birim değişmeye bir değişmeye, genişleme döneminde ise ithalat değişkeninin cari dönem değerinde meydana gelen bir birimlik değişme ekonomik büyüme üzerinde 0.0592 birim değişmeye ve ithalat değişkenin bir dönem gecikmeli değerinde meydana gelen bir birimlik değişme ekonomik büyüme üzerinde 0.0537 birim değişmeye neden olmaktadır. Bununla birlikte modelde yer alan diğer değişkenlere ait katsayılar incelendiğinde ise istihdam hacmi büyüme oranının ihracat ve ithalat değişkenlerinin yer aldığı modellerin genelinde ekonomik büyüme üzerinde istatistiksel açıdan anlamsız olmakla birlikte negatif bir etki yaptığı görülmektedir. Bu durumu analiz etmek amacıyla Türkiye ekonomisinde ekonomik büyüme ile istihdam ilişkisini araştıran çalışmalar incelendiğinde, söz konusu çalışmalarda da istihdamın ekonomik büyüme üzerinde anlamlı bir etki yapmadığı bulgusunu elde ettikleri tespit edilmektedir. Bu çalışmalardan örneğin Polat vd. (2011)'nin 1950-2006 dönemine kapsayan ve sınır testi eşbütünleşme yaklaşımını benimsedikleri çalışmalarında kısa ve uzun dönemde istihdamın ekonomik büyüme üzerinde negatif fakat istatistiksel olarak anlamsız bir etkisi olduğu sonucuna ulaştıkları görülürken, benzer şekilde Muratoğlu (2011)'nun 2000-2011 arasındaki çeyrek dönem verilerini kullanarak gerçekleştirdiği çalışmasında da ekonomik büyüme ile istihdam arasında herhangi bir Granger nedensellik ilişkisi olmadığı sonucunu elde ettiği görülmektedir. Bu şekilde yerleşik iktisat teorisine ters bir sonucun oluşmasında ise Türkiye'de düşük nitelikli işgücü olarak kabul edilebilecek olan okuryazar olmayan ve lisealtı eğitim seviyesine sahip kişilerin toplam istihdam içerisinde yaklaşık 
yüzde $48^{\prime}$ lik bir orana sahip olmasının ve toplam istihdamın yaklaşık yüzde 74'ünün² diğer sektörler ile karşılaştııılığında çalışılan saat başına katma değerin göreceli olarak düşük olduğu hizmet ve tarım sektörlerinin oluşturmasının etkili olabileceği düşünülmektedir ${ }^{3}$. Bu tespitler bir anlamda Türkiye'de istihdam açısından azalan verimler yasasının geçerli olabileceğine işaret etmektedir. Son olarak ihracat ve ithalat değişkenlerinin yer aldıkları model içerisinde yer alan $(\Delta(I / Y))$ değişkeninin ekonomik büyüme üzerindeki etkisi incelendiğinde söz konusu değişkenin ihracat değişkeninin yer aldığı modelde daralma dönemindeki cari dönem değerinin ekonomik büyüme üzerinde pozitif fakat istatistiksel açıdan anlamsIz, bir gecikmeli değerinin ekonomik büyüme üze- rinde negatif, genişleme dönemindeki cari dönem ve bir dönem gecikmeli değerinin ekonomik büyüme üzerinde pozitif bir etki yaptığı; ithalat değişkeninin yer aldığı modelde $(\Delta(I / Y))$ değişkenin daralma dönemindeki cari ve bir dönem gecikmeli değerlerinin ekonomik büyüme üzerinde negatif fakat istatistiksel açıdan anlamsız, genişleme dönemindeki cari dönem değerinin ekonomik büyüme üzerinde pozitif, bir dönem gecikmeli değerinin ise ekonomik büyüme üzerinde pozitif fakat istatistiksel açıdan anlamsız bir etki yaptığı görülmektedir ${ }^{4}$. Bu sonuçun oluşmasında ise daralma dönemlerinin özellikle kriz dönemlerini kapsaması ve bu dönemlerde de Şekil 1'den de görüleceği üzere $(\Delta(I / Y))$ serisinin negatif değerler almasının etkili olduğu düşünülmektedir.

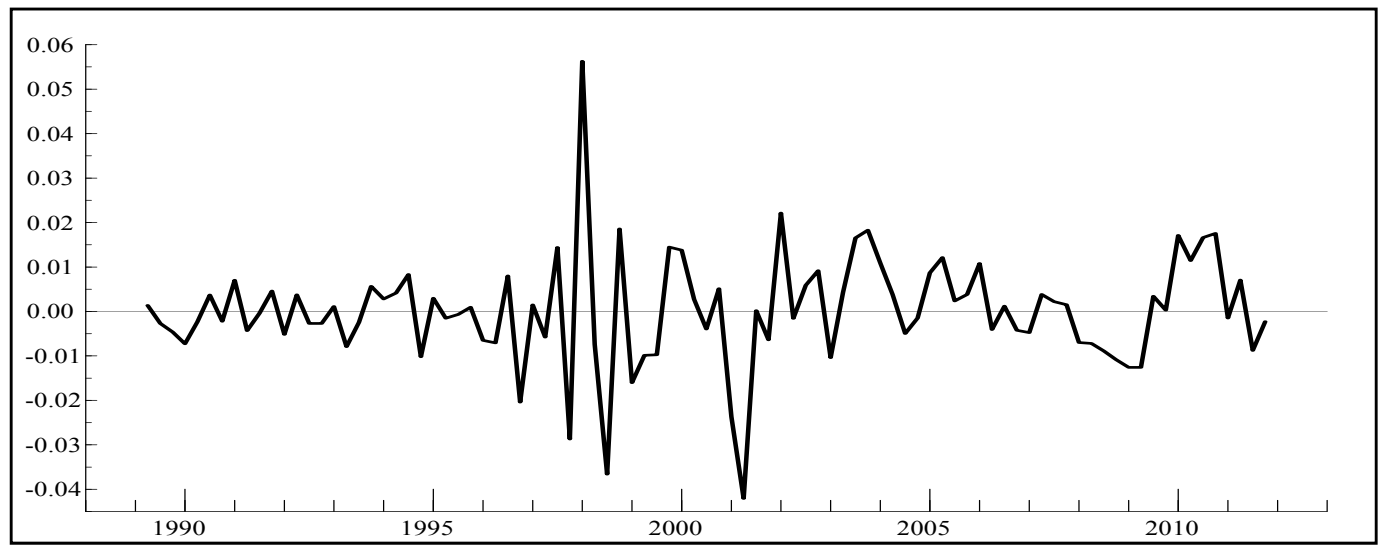

Şekil 1: Birinci Farkı Alınmış (I / Y) Serisi (1989:2-2011:4)

Tablo 5: MSIA(2)-ARX(1)Modeli Analiz Sonuçları

\begin{tabular}{|c|c|c|c|c|}
\hline \multirow{2}{*}{ Bağımsız Değişkenler } & \multicolumn{2}{|c|}{$\begin{array}{l}\text { Daralma Dönemi } \\
\text { Analiz Sonuçları }\end{array}$} & \multicolumn{2}{|c|}{$\begin{array}{c}\text { Genişleme Dönemi } \\
\text { Analiz Sonuçları }\end{array}$} \\
\hline & Katsayılar & $\begin{array}{c}\text { (t-istatistik) } \\
\text { Değerleri }\end{array}$ & Katsayılar & $\begin{array}{l}\text { (t-istatistik) } \\
\text { Değerleri }\end{array}$ \\
\hline Sabit Terim & -0.0419 & $-3.9569^{*}$ & 0.0112 & $4.8429^{*}$ \\
\hline$(\dot{Y})_{t-1}$ & -0.7482 & $-3.3785^{*}$ & -0.2014 & $-2.8025^{*}$ \\
\hline$(\dot{L})$ & -1.9239 & -1.7829 & -0.0736 & -0.8406 \\
\hline$(\dot{L})_{t-1}$ & -1.4940 & -0.9150 & -0.1011 & -1.1698 \\
\hline$(\Delta(I / Y))$ & 1.3634 & 1.1853 & 0.2639 & $6.4054^{*}$ \\
\hline$(\Delta(I / Y))_{t-1}$ & -2.1711 & $-3.3002^{*}$ & 0.0769 & $2.4327^{*}$ \\
\hline$(\dot{X})$ & 0.0155 & 0.0741 & 0.2639 & $6.4054^{*}$ \\
\hline$(\dot{X})_{t-1}$ & 0.6604 & $4.5444^{*}$ & 0.0769 & $2.4327^{*}$ \\
\hline \multicolumn{5}{|c|}{ Doğrusallık Testi Davies Olasılık Değeri : 0.0000} \\
\hline Bağımsız Değişkenler & $\begin{array}{l}\text { Daralma } \\
\text { Analiz S }\end{array}$ & $\begin{array}{l}\text { Dönemi } \\
\text { onuçları }\end{array}$ & $\begin{array}{l}\text { Genişle } \\
\text { Analiz }\end{array}$ & $\begin{array}{l}\text { Dönemi } \\
\text { nuçları }\end{array}$ \\
\hline
\end{tabular}




\begin{tabular}{|c|c|c|c|c|}
\hline \multicolumn{5}{|c|}{ Doğrusallık Testi Davies Olasılık Değeri : 0.0000} \\
\hline \multirow{2}{*}{\begin{tabular}{|l} 
Bağımsız Değiş̧kenler \\
Bağımsız Değişkenler
\end{tabular}} & \multicolumn{2}{|c|}{$\begin{array}{l}\text { Daralma Dönemi } \\
\text { Analiz Sonuçları }\end{array}$} & \multicolumn{2}{|c|}{$\begin{array}{l}\text { Genişleme Dönemi } \\
\text { Analiz Sonuçları }\end{array}$} \\
\hline & Katsayılar & \begin{tabular}{|c|} 
(t-istatistik) \\
Değerleri
\end{tabular} & Katsayılar & $\begin{array}{l}\text { (t-istatistik) } \\
\text { Değerleri }\end{array}$ \\
\hline Sabit Terim & -0.0021 & -0.7250 & 0.0195 & $8.1433^{*}$ \\
\hline$(\dot{Y})_{t-1}$ & -0.1991 & -1.2565 & -0.4441 & $-5.3507^{*}$ \\
\hline$(\dot{L})$ & 0.6247 & $4.1625^{*}$ & -0.0524 & -0.5169 \\
\hline$(\dot{L})_{t-1}$ & -0.1568 & -1.0311 & 0.0180 & 0.1776 \\
\hline$(\Delta(I / Y))$ & -0.0424 & -0.1961 & 0.5790 & $3.0731^{*}$ \\
\hline$(\Delta(I / Y))_{t-1}$ & -0.1067 & -0.4739 & 0.0766 & 0.3915 \\
\hline$(\dot{M})$ & 0.2921 & $13.0269^{*}$ & 0.0592 & $2.4586^{*}$ \\
\hline$(\dot{M})_{t-1}$ & 0.1421 & $2.5125^{*}$ & 0.0537 & $2.6295^{*}$ \\
\hline \multicolumn{5}{|c|}{ Doğrusallık Testi Davies Olasılık Değeri : 0.0000} \\
\hline
\end{tabular}

Söz konusu daralma ve genişleme dönemlerinin geçiş olasılıkları matrisi ve rejim özellikleri Tablo 6'da gösterilmiştir.

Tablo 6: Geçiş Olasıkları Matrisi ve Rejim Dönemleri

\begin{tabular}{|c|c|c|c|}
\hline \multicolumn{4}{|c|}{$\begin{array}{c}\text { İhracat Değişkeninin Yer Aldığı Modelde Geçiş Olasılıkları } \\
\text { Matrisi ve Rejim Özellikleri }\end{array}$} \\
\hline \multicolumn{4}{|c|}{ 1- Geçiş Olasıkları Matrisi } \\
\hline Rejimler & \multicolumn{2}{|c|}{$\begin{array}{l}\text { Daralma } \\
\text { Rejimi }\end{array}$} & $\begin{array}{l}\text { Genişleme } \\
\text { Rejimi }\end{array}$ \\
\hline Daralma Rejimi & \multicolumn{2}{|c|}{0.4141} & 0.5859 \\
\hline Genişleme Rejimi & \multicolumn{2}{|c|}{0.0626} & 0.9374 \\
\hline \multicolumn{4}{|l|}{ 2- Rejim Özellikleri } \\
\hline Rejimler & $\begin{array}{c}\text { Gözlem } \\
\text { Sayısı }\end{array}$ & $\begin{array}{l}\text { Olasılık } \\
\text { Değeri }\end{array}$ & $\begin{array}{c}\text { Ortalama Süre } \\
\text { (Çeyrek } \\
\text { Dönem) }\end{array}$ \\
\hline Daralma Rejimi & 8.9 & 0.0966 & 1.71 \\
\hline Genişleme Rejimi & 79.1 & 0.9034 & 15.97 \\
\hline \multicolumn{4}{|c|}{$\begin{array}{c}\text { İthalat Değişkeninin Yer Aldığı Modelde Geçiş Olasılıkları } \\
\text { Matrisi ve Rejim Özellikleri }\end{array}$} \\
\hline \multicolumn{4}{|c|}{ 1- Geçiş Olasıkları Matrisi } \\
\hline Rejimler & \multicolumn{2}{|c|}{$\begin{array}{l}\text { Daralma } \\
\text { Rejimi }\end{array}$} & $\begin{array}{l}\text { Genişleme } \\
\text { Rejimi }\end{array}$ \\
\hline Daralma Rejimi & \multicolumn{2}{|c|}{0.8175} & 0.1825 \\
\hline Genişleme Rejimi & \multicolumn{2}{|c|}{0.1605} & 0.8395 \\
\hline \multicolumn{4}{|l|}{ 2- Rejim Özellikleri } \\
\hline Rejimler & $\begin{array}{c}\text { Gözlem } \\
\text { Sayısı }\end{array}$ & $\begin{array}{l}\text { Olasılık } \\
\text { Değeri }\end{array}$ & $\begin{array}{c}\text { Ortalama Süre } \\
\text { (Çeyrek } \\
\text { Dönem) }\end{array}$ \\
\hline Daralma Rejimi & 42.9 & 0.4680 & 5.48 \\
\hline Genişleme Rejimi & 46.1 & 0.5320 & 6.23 \\
\hline
\end{tabular}


Tablo 6'daki sonuçlara göre ihracat değişkenin yer aldığı modelde, ekonomi daralma rejiminde iken daralma rejiminde kalma olasılığı yüzde 41, söz konusu rejimde iken genişleme rejimine geçme olasılığı yüzde 58, ekonomi genişleme rejiminde iken daralma rejimine girme olasılığı yüzde 6 , genişleme rejimde iken genişleme rejiminde kalma olasılığı yüzde 93; ithalat değişkenin yer aldığı modelde ise, ekonomi daralma rejiminde iken daralma rejiminde kalma olasılığının yüzde 81, söz konusu rejimde iken genişleme rejimine geçme olasılığı yüzde 18, ekonomi genişleme rejiminde iken daralma rejimine girme olasııı̆ı yüzde 16 , genişleme rejimde iken genişleme rejiminde kalma olasıı̆ğı yüzde 83 olarak belirlenmiştir. Bu sonuçlar ile birlikte Tablo 6'da, ithalatın yer aldığı modelde ekonominin daralma dönemde kalma olasılığının ihracatın yer aldığı modele göre daha yüksek olduğu görülmektedir. Bu sonuç Türkiye'de toplam üretimin büyük ölçüde dışa bağımlı olduğunu ve olasılı ithalat tıkanıkları karşısında ekonominin daralma dönemine girme olasılığının yüksek olduğunu göstermektedir5. Tablo 6'da sonuçlara ilave olarak her iki model hesaplanmış geçiş olasılıkları sırasıyla ihracatın ve ithalatın yer aldığı modeller için sırasıyla Sekil 2 ve 3 'te gösterilmiştir.

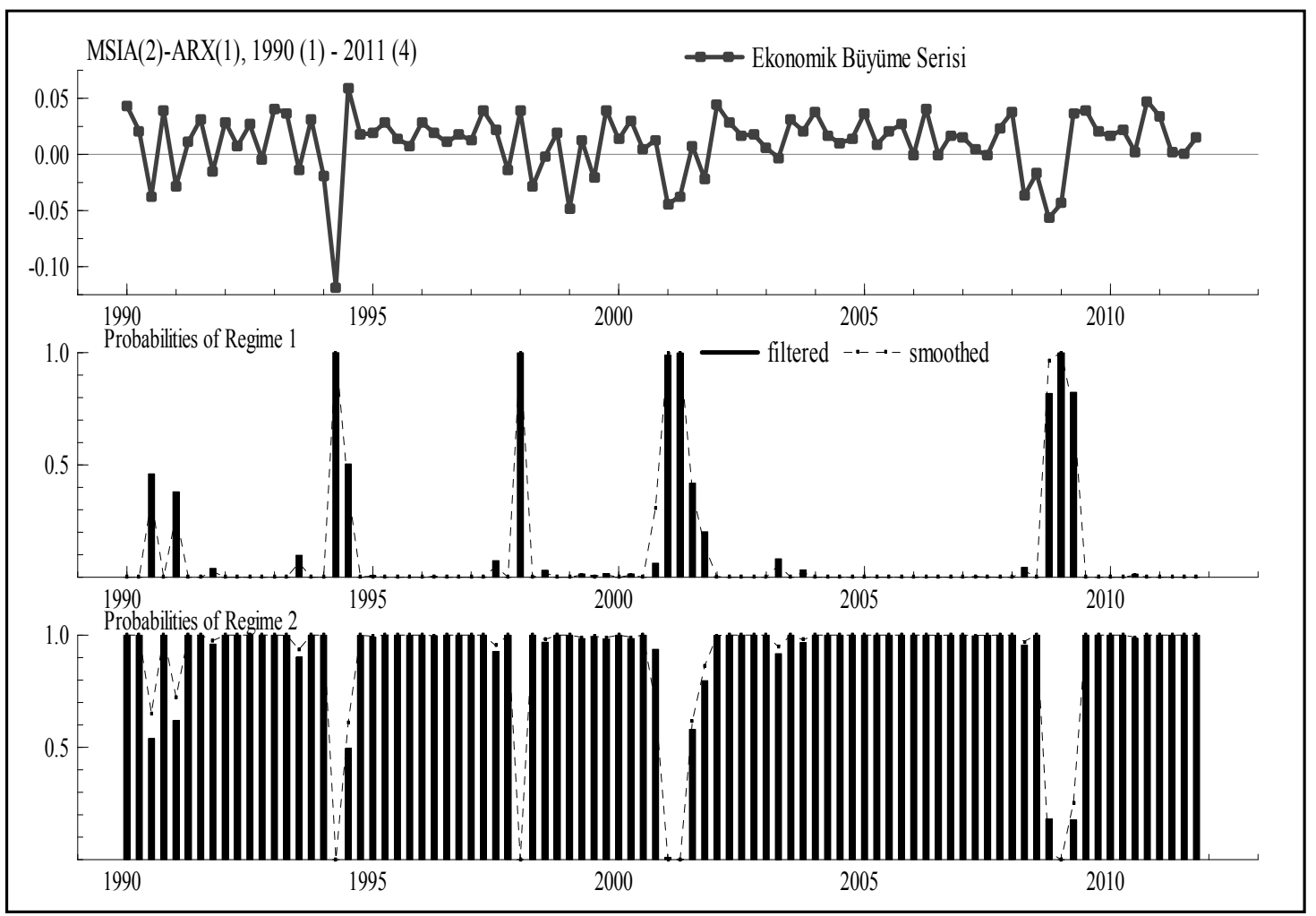

Şekil 2: Daralma ve Genişleme Dönemleri Geçiş Olasılıkları-1

(Not: Probabilities of Regime 1.Daralma Rejimi Olasılıkları, Probabilities of Regime 2. Genişleme Rejimi Olasılıkları, Filtered: Filtrelenmiş, Smoothed: Düzgünleştirilmiş) 


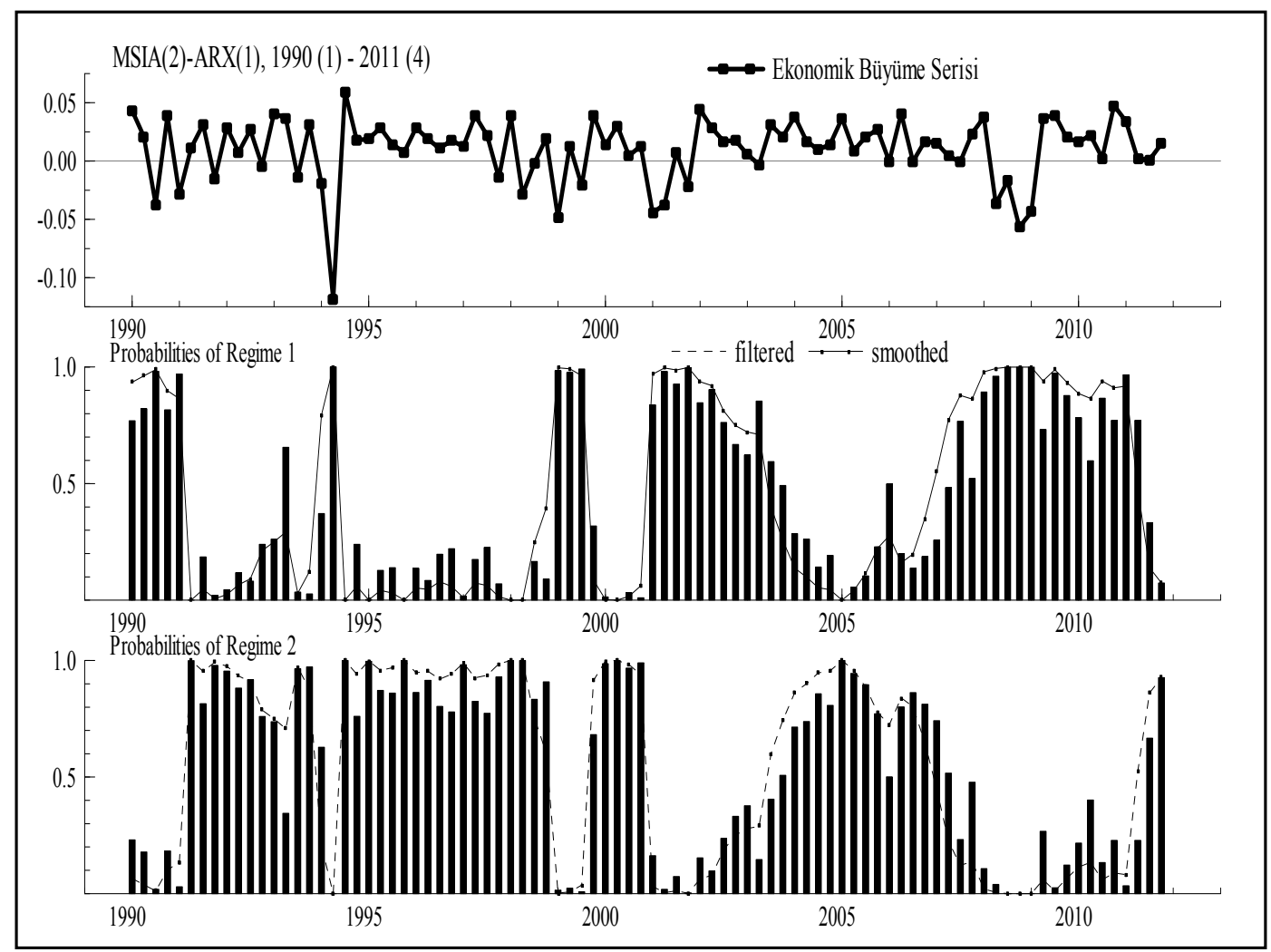

Şekil 3: Daralma ve Genişleme Dönemleri Geçiş Olasılıkları-2

(Not: Probabilities of Regime 1: Daralma Rejimi Olasılıkları, Probabilities of Regime 2: Genişleme Rejimi Olasılıkları, Filtered: Filtrelenmiş, Smoothed: Düzgünleştirilmiş)

Şekil 2 ve 3' teki rejim olasılıklarına bakıldığında daralma dönemlerinin ihracat ve ithalatın yer aldığı modellerin her ikisinde de ekonomik büyüme serisine paralel bir seyir izlediği ve ekonomik büyümenin negatif seyir izlediği dönemlerde ekonominin daralma döneminde olma olasılığının yükseldiği buna karşılık pozitif bir seyir izlediği dönemlerde de genişleme döneminde yer alma olasılığının yükseldiği gözlenmektedir. Özellikle Türkiye'de yaşanan 1994 ve 2001 krizleri ile 2008'de Amerika Birleşik Devletleri'nde yaşanan başta Avrupa ülkeleri olmak üzere birçok ülkeyi etkileyen finansal kriz dönemlerinde ekonominin daralma döneminde kalma olasıllğının yükseldiği görülmektedir.

\section{SONUÇ}

İhracat, ithalat ve ekonomik büyüme arasındaki ilişkilerin uzun yıllardır iktisatçıların gündeminde yer alan başlıca inceleme konusu olduğu ve konu ile ilgili geniş bir teorik altyapının oluştuğu görülmektedir. Bu teorik altyapı kısaca özetlenmek istenildiğinde ekonomik büyüme ile gerek ihracat gerekse de ithalat arasında karşılıklı bir etkileşim olduğu tespit edilmektedir. Buna göre ihracata yönelik sanayileşme hi- potezinde, ihracatın ülke içerisindeki atıl kaynakların kullanımını teşvik ederek ekonomi büyümeyi olumlu yönde etkileyeceği iddia edilirken Vernon (1966)'da teknolojik gelişme ve yatırım kapasitesinde meydana gelen artış sonucu ortaya çıkan ekonomik büyüme sonucu ülkeninin rekabet gücünün yükseleceği ve ihracat kapasitesinin artacağı iddia edilmektedir ${ }^{6}$. Bununla beraber Keynezyen modellerde konu çarpan mekanizması yardımıyla analiz edilmekte ve inracat artışlarının ve ithalat azalışlarının ekonomik büyümeyi olumlu yönde etkilediği kabul edilmektedir. Içsel ekonomik büyüme modellerinde ise sermaye ve yatırım malı ithalatı yoluyla gerçekleştirilen teknoloji transferinin ekonomik büyümeye olumlu katkı sağlayacağı savunulmaktadır. Fakat ekonomik büyümenin artması beraberinde ithalat talebini de yükseltebilmektedir. Bu anlamda ithalat ile ekonomik büyüme arasında karşılıklı bir etkileşim ortaya çıkmaktadır. Bu bağlamda hazırlanan bu çalışmada, doğrusal olmayan model çözümlemesi ile ekonominin içerisinde bulunduğu daralma ve genişleme dönemlerinde özellikle ihracat ve ithalatın ekonomik büyümeye olan katkıları araştırı mıştır. Diğer bir deyişle bu çalışmada ihracata yönelik sanayileşme hipotezi ile içsel 
ekonomik büyüme yaklaşımının ithalat ve ekonomik büyüme ilişkisi ile ilgili görüşlerinin geçerliliklerinin sınanması amaçlanmıştır. Çalışmada farklı bir ekonometrik yöntemin benimsenmesinin nedeni ise bu yöntemin ekonominin daralma ve genişleme dönemlerine karşılık gelen gözlemlerini ayrıştırabilmesi ve sadece ilgili dönemlerde yer alan gözlemler kullanılarak tahminleme yapılmasına izin vermesidir. Bu nedenle, ekonominin içerisinde bulunduğu daralma ve genişleme dönemlerinde uygulanan iktisat politikalarının etkinliklerini bu yöntemle ortaya koymak mümkün hale gelebilmektedir. Söz konusu bu avantajları nedeniyle benimsenen ekonometrik yöntemin sonuçlarına bakıldığında ise daralma döneminde ihracatın bir gecikmeli ${ }^{7}$, ithalatın cari dönem ve bir dönem gecikmeli değerleri ile genişleme dönemindeki söz konusu değişkenlerin bir gecikmeli ve cari dönem değerlerinin ekonomik büyümeyi pozitif yönde etkilediği ve olası ithalat tıkanıkları karşısında ekonominin daralma dönemine girme olasılığının yüksek olduğu belirlenmiştir. Elde sonuçlar Türkiye'de izlenen dış ticaret politikaları açısından değerlendirildiğinde, Türkiye'de 24 Ocak 1980 sonrası benimsenen ihracata yönelik sanayileşme stratejisinin ilgili dönemde ihracatın ithalata olan bağımlılığını artırıcı bir etki yaptığı görülmektedir.
Bu durumun oluşmasında ise 1930'lardan 1980'e kadar ki dönemde uygulanan ithal ikameci sanayileşme stratejisinin ilk aşamasında dış koruma altında tüketim malları sektörüne ilişkin malların üretilmesinde başarı elde edilmesine karşın, bu stratejinin ikinci ve zor aşaması olarak kabul edilen ara ve yatırım malı üretilmesi aşamasında istenilen başarının elde edilememesinin etkili olduğu ifade edilmektedir (Egeli, 2001: 157). Ara ve yatırım malı üretilmesi aşamasındaki bu başarısızlığın ardından benimsenen ihracata yönelik sanayileşme stratejisi çerçevesinde ihracatın teşvik edilmesi ise beklenildiği gibi ihracatta önemli artışların gerçekleştirilmesini mümkün kılmış fakat ara ve yatırım malı taleplerinin yurtiçi üretim ile yeterince karşılanamaması sonucunda ekonominin ara ve yatırım malı ithalatına olan bağımlılığı artmışıır Fakat her ne kadar ekonominin ara ve yatırım malı ithalatına olan bağımlıı̆ı̆ının artması dolaylı-dolaysız sermaye yatırımları ve ihracat sayesinde elde elde edilen dövizler ile karşılanabilse de 1930-1937 ve 1939-1946 arası dönemlerin dışında 1923'ten 2011 yılına kadar her yıl dış ticaret açığı yaşanan Türkiye'de döviz ihtiyacının özellikle 1989 yılındaki finansal serbestleşme kararlarından sonra büyük ölçüde dolaylı yabancı sermaye yatırımları ile karşılanmasının ekonomideki kırılganlığı artırdığı düşünülmektedir. Bu kırılganlığın azaltılması ve sürdürülebilir kalıcı ekonomik büyümenin sağlanması noktasında ise ara ve yatırım malı yurtiçinde üretimini teşvik edecek politikaların uygulanması gerekmektedir. 


\section{SON NOTLAR}

${ }^{1}$ http://www.tuik.gov.tr, http://www.dpt.gov.tr

2 http://www.tuik.gov.tr

3 Örneğin, 2008 yılı itibariyle sanayi sektöründeki çalışılan saat başına katma değer yaklaşık 19 TL, iken, hizmet sektöründe yaklaşık 6.24 olduğu görülmektedir. Bknz. http://vi.sanayi.gov.tr/rprU.aspx.

4 Çalışmada istatistiksel açıdan anlamsız olarak belirtilmeyen değişkenlerin istatistiksel açıdan anlamlı olduğu kabul edilmektedir. Fakat her bir değişken için bu ifadenin tekrarlanmasına gerek duyulmamıştır.

5 İthalatın yer aldığı modele, ihracatın da dahil edilmesi durumunda ekonominin daralma rejiminde iken daralma rejiminde kalma olasılığı $(0.8125)$ olarak tespit edilmiştir.

6 Bknz. Bilgin ve Şahbaz, 2009, Vernon, 1966 ve Jin, 2002.

7 Özellikle daralma döneminde ihracatın bir gecik-

\section{KAYNAKLAR}

Aktaş, C. (2009) “Türkiye'nin İhracat, İthalat ve Ekonomik Büyüme Arasındaki Nedensellik İlişkisi” Kocaeli Üniversitesi Sosyal Bilimler Enstitüsü Dergisi, $18(2): 35-47$.

Ay, A., Erdoğan, S. ve Mucuk, M. (2004) “Türkiye'de İhracata Dayalı Büyüme Üzerine Bir Nedensellik Sinaması (1980-2003)" Selçuk Üniversitesi Karaman İktisadi ve İdari Bilimler Fakültesi Dergisi, 4(1):107-117.

Barışık, S., Çevik, E.İ. ve Çevik, K.N. (2010) "Türkiye'de Okun Yasası, Asimetri İlişkisi ve İstihdam Yaratmayan Büyüme: Markov-Switching Yaklaşımı” Maliye Dergisi, 159:88-102.

Bildirici, M. ve Bozoklu, Ü. (2007) "Bireysel Beklentiler ve Çoklu Ekonomik Denge: Markov Geçiş Modeli”, 8. Türkiye Ekonometri ve İstatistik Kongresi, Mayıs 24-25, Malatya.

Bilgin, C. ve Şahbaz, B. (2009) “Türkiye'de Büyüme ve İhracat Arasındaki Nedensellik İlişkileri” Gaziantep Üniversitesi Sosyal Bilimler Dergisi, 8(1):177-198.

Clements, M.P., Franses, P.H ve Swanson, N.R. (2004) "Forecasting Economic and Financial TimeSeries with Non-Linear Models" International Journal of Forecasting, 20:169-183.

Çetintaş, B. ve Barışık (2009) "Export, Import and Economic Growth: The Case of Transition Economies" Transition Studies Review, 15(4):636-649. meli değerlerinin ekonomik büyümeyi etkilemesinin ise ihracatçıların bu dönemde dış satımlarını kolaylaştırmak için uzun vadeli sözleşmelerle dış satımı gerçekleştirdiklerini göstermektedir. Zira, Türkiye'de genellikle ihracatta ödeme şekli olarak mal mukabili ödeme yöntemi benimsenirken, ithalatta ise peşin ödeme yönteminin benimsendiği görülmektedir. (Bknz http://www.tuik. gov.tr/VeriBilgi.do?alt_id=12.) Buna göre, mal mukabili ödeme yönteminde, firmalar ürünlerinin ihraç ettikten sonra ürün bedellerini tahsil etmektedirler. Dolayısıyla da ürünlerin ihraç edildikleri tarih ile ürün bedellerinin firmalara ödendiği tarih arasında fark ortaya çıkmaktadır.

81980 sonrası dönemde ara ve yatırım malı ithalatının toplam ithalat içerisindeki payının yüzde $85^{\prime}$ in altına inmediği görülmektedir. Bknz. http://www.dpt.gov.tr

${ }^{9}$ Bu çalışma, 11-12 Eylül 2012 tarihinde Tetova Üniversitesinde düzenlenen 4. Uluslararası Balkanlarda Sosyal Bilimler Kongresinde sunulan bildirinin genişletilmiş şeklidir.

Çiftçi, C. ve Aykaç, G. (2011) “İçsel Büyüme Modelleri ve Küreselleşme Sürecinde Gelişmekte Olan Ülkelerin Konumları" Sosyoekonomi, 7(14): 159-180.

Demirhan, E. (2005) "Büyüme ve İhracat Arasındaki Nedensellik İlişkisi: Türkiye Örneği” Ankara Üniversitesi Siyasal Bilgiler Fakültesi Dergisi, 60(4):76-88.

Egeli, H.A. (2001) "Dış Ticaret Açısından Sanayileşme Stratejileri ve Türkiye Uygulaması" Manas Üniversitesi Sosyal Bilimler Dergisi, 3(7):149-161.

Erdoğan, S. (2006) “Türkiye’nin İhracat Yapısındaki Değişme ve Büyüme İlişkisi: Koentegrasyon ve Nedensellik Testi Uygulaması" Selçu Üniversitesi Karaman İktisadi ve İdari Bilimler Fakültesi Dergisi, 10:30-39.

Gerni, C., Emsen, Ö.S. ve Değer, M.K. (2008) "İthalata Dayalı İhracat ve Ekonomik Büyüme: 19802006 Türkiye Deneyimi” 2. Ulusal İktisat Kongresi, Şubat 20-22, İzmir.

Grossman, G.M. ve Helpman, E. (1994) "Endogenous Innovation in the Theory of Growth" Journal of Economic Perspectives, 8(1):23-44.

Grossman, G.M. ve Helpman, E. (1995) "Technology and Trade" Grossman et al.(eds.) Handbook of International Economics, 1st Edition, USA, Elsevier.

Güngör, B. ve Kurt, S. (2007) "Dışa Açıklık ve Kalkınma İlişkisi (1968-2003): Türkiye Örneği” Atatürk Üniversitesi İktisadi ve İdari Bilimler Fakültesi Dergisi, 21(2):197-210. 
İspir, S., Ersoy, B.A. ve Yılmazer, M. (2009) "Türkiye’nin Büyüme Dinamiğinde İhracat mı İthalat mı Daha Etkin?” Dokuz Eylül Üniversitesi İktisadi ve İdari Bilimler Fakültesi Dergisi, 24(1): 59-72.

Jin, J.C. (2002) "Exports and Growth: Is the Export-Led Growth Hypothesis Valid for Provincial Economies?" Applied Economics, 34:63-76.

Karluk, R. (2009) Uluslararası Ekonomi, 9. Baskı, İstanbul, Beta Basım Yayım Dağıtım A.Ş.

Kazgan, G. (1998) "İktisat Kuramı-Politikası ve Büyüme Stratejisi” Serin, V. (eds.) İktisat Politikası, 1. Baskı, İstanbul, Alfa Basım Yayım Dağıtım Ltd. Şti.

Koç, S. (2008) “Tek ve Çok Değişkenli Rejim Değişim Modellerinin Türkiye Ekonomik Göstergelerine Uygulanması" Yayınlanmamış Doktora Tezi, İstanbul, Marmara Üniversitesi Sosyal Bilimler Enstitüsü.

Kotil, E. ve Konur, F. (2010) "The Relationship Between Growth and Foreign Trade in Turkey: A Granger Causality Approach (1989-2007)" Middle Eastern Finance and Economics, 6:1450-2889.

Kösekahyaoğlu, L., C. Şentürk, (2006) "İhracata Dayalı Büyüme Hipotezinin Testi: Türkiye ve Yeni Gelişen Ekonomiler Üzerine Karşılaştırmalı Bir İnceleme" Süleyman Demirel Üniversitesi Sosyal Bilimler Enstitüsü Dergisi, 2(4):23-45.

Krolzig, H.M. (1998) Econometric Modelling of Markov-Switching Vector Autoregressions using MSVAR for $O x$, Institute of Economics and Statistics and Nuffield College, Oxford.

Lee, J. ve Strazicich, M.C. (2003) "Minimum Lagrange Multiplier Unit Root Test with Structural Breaks" The Review of Economics and Statistics, 85(4):1082-1089.

Medina-Smith, E.J. (2001) "Is the Export-Led Growth Hypothesis Valid for Developing Countries? A Case Study of Costa-Rica" Policy Issues in International Trade and Commodities Study Series, No:7.

Muratoğlu, Y. (2011) "Büyüme ve İstihdam Arasındaki İlişki" International Conference on Eurasian Economies, Yayınlanmış Bildiri, 12-14 Ekim, Bişkek.

Nişanc1, M. (2005) "Dış Ticaret Beşeri Sermaye ve İktisadi Gelişme Arasındaki Uzun Dönem Nedensellik İlişkisinin Testi” Atatürk Üniversitesi Erzincan Hukuk Fakültesi Dergisi, 9(1-2): 675-687.

Özer, M. ve Erdoğan, L. (2006) “Türkiye'de İhracat, İthalat ve Ekonomik Büyüme Arasındaki İlişkilerin Analizi” Ekonomik Yaklaşım, 17(60-61):93-110.
Özmen, E. ve Furtun, G. (1998) "Export-led Growth Hypothesis and the Turkish Data: An Empirical Investigation" METU Studies in Development, 25(3):491503.

Özmen, A, Özer, M. ve Türkyılmaz, S. (1999) Türkiye'de İhracat ve Ekonomik Büyüme Arasindaki Nedenselliğe İlişkin Bir Uygulama Denemesi, Marmara Üniversitesi Yayını, No: 640.

Polat, Ö., Uslu, E.E. ve Sayın, S. (2011) “Türkiye’de Elektrik Tüketimi, İstihdam ve Ekonomik Büyüme İlişkisi” Süleyman Demirel Üniversitesi İktisadi ve İdari Bilimler Fakültesi Dergisi 16(1):349-362.

Ram, R. (1985) "Exports and Economic Growth: Some Additional Evidence" Economic Development and Cultural Change, 33(2):415-425.

Safdari, M., Mahmoodi, M. ve Mahmoodi, E. (2011) "The Causality Relationship Between Export and Economic Growth in Asian Developing Countries" American Journal of Scientific Research, 25:40-45.

Seyidoğlu, H. (2007) Uluslararası İktisat, İstanbul, Güzem Can Yayınları.

Shaw, G.K. (1992) "Policy Implications of Endogenous Growth Theory" The Economic Journal, 102(412):611-621.

Shirazi, N.S., ve Manap, T.A.A. (2004) "ExportLed Growth Hypothesis: Further Econometric Evidence from South Asia" The Developing Economies, 43(4):472488.

Soyyiğit, S. (2010) "Türkiye'de İhracata Dayalı Sanayileşme Stratejisi Uygulamaları ve İmalat Sanayii Üzerindeki Etkinliği: Nedensellik Analizi (19802008)" İstanbul Üniversitesi İktisat Fakültesi Mecmuası, 60(2):135-156.

Şimşek, M. (2003) "İhracata Dayalı-Büyüme Hipotezinin Türkiye Ekonomisi Verileri İle Analizi, 1960-2002" Dokuz Eylül Üniversitesi İktisadi ve İdari Bilimler Fakültesi Dergisi, 18(2):43-63.

Şimşek, M. ve Kadılar, C. (2010) “Türkiye'de Beşeri Sermaye, İhracat ve Ekonomik Büyüme Arasındaki İlişkinin Nedensellik Analizi” Cumburiyet Üniversitesi İktisadi ve İdari Bilimler Fakültesi Dergisi, 11(1):115140.

Taban, S. ve Aktar, İ. (2008) "An Empirical Examination of the Export-led Growth Hypothesis in Turkey" Journal of Yasar University, 3(11):1535-1551.

Takım, A. (2010) “Türkiye'de GSYİH ile İhracat Arasındaki İlişki: Granger Nedensellik Testi” Atatürk Üniversitesi Sosyal Bilimler Enstitüsü Dergisi,14(2):1-16. 
Temiz, D. ve Gökmen A. (2010) "An Analysis of the Export and Economic Growth in Turkey Over the Period of 1950-2009" International Journal of Economic and Administrative Studies, 3(5):123-142.

Tuncer, İ. (2002) “Türkiye'de İhracat, İthalat ve Büyüme-Toda-Yamamoto Yöntemiyle Granger Nedensellik Analizleri” Çukurova Üniversitesi Sosyal Bilimler Enstitüsü Dergisi, 9(9): 89-107.

Uğur, A. (2008) "Import and Economic Growth in Turkey: Evidence from Multivariate VAR Analysis" Journal of Economics and Business, 11(1-2):54-75.

Utkulu, U. ve Özdemir, D. (2004) "Does Trade Liberalization Cause a Long Run Economic Growth" Economics of Plannig, 37:245-266.
Vernon, R. (1966) "International Investment and International Investment and International Trade in the Product Cycle" Quarterly Journal of Economics, 80:290307.

Yapraklı, S. (2007) "İhracat ile Ekonomik Büyüme Arasındaki Nedensellik:Türkiye Ekonomisi Üzerine Ekonometrik Bir Analiz" ODTÜ Gelişme Dergisi, 34(1):97-112.

Yiğidim, A. ve Köse, N. (1997) "İhracat ve Ekonomik Büyüme Arasındaki İlişki” Ekonomik Yaklaşım, 8(26):7185. 